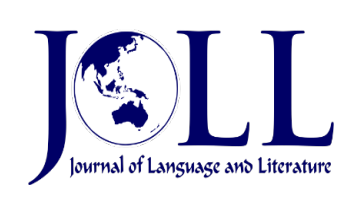

\title{
A Linguistic Analysis of Mobile Phone Companies' Slogans: A Case of Vodacom and Tigo in Tanzania
}

\author{
Peter Rabson Mziray \& Bazili Evarist Bamuhiga \\ petermziray@sua.ac.tz \& bazili.bamuhiga@sua.ac.tz \\ Department of Language Studies, Sokoine University of Agriculture, TANZANIA
}

\begin{abstract}
This paper presents findings of a Linguistic Analysis of Mobile Phone Companies' Slogans: a case of Vodacom and Tigo in Tanzania. It specifically aimed at analysing linguistics forms used in constructing mobile phone companies' slogans and examining the type of illocutionary acts portrayed by the slogans. A total of 25 slogans were collected from online websites of the Tigo and Vodacom mobile phone companies using documentation method and analysed using content analysis. The findings indicate that slogans from mobile phone companies mostly use sentences and, in some instances, phrases and words. Also, the findings revealed that the dominant illocutionary speech acts embedded in the slogans is assertive which intends to change the beliefs of the customer. The other illocutionary speech acts identified are directive which requires the customers to take action in regard to the services and products advertised; and commissive which shows a promise for better services and products for opting customers. Conclusively, mobile phone companies prefer to use sentences and, in few instances, paired phrases to construct the slogans. The constructed slogans largely portray assertive acts which are complemented by commissive and directive acts. The complementation is what makes mobile phone companies have more than one slogan for communicating a complete intended message.
\end{abstract}

Article information

Keywords: Slogan; Adverts; Mobile Phone companies; Tanzania

\section{Introduction}

Mobile phone technology is central to digital transformations in Tanzania. The market of mobile phone operation in Tanzania has been growing both in numbers of subscribers and the operators. Mobile phone network operation in Tanzania started with only one company which according to Mtenzi, Chachage and Ngumbuke (2008) was Mobitel, currently known as Tigo. However, currently there are seven mobile network companies in operation namely Airtel, Halotel, Smile, Tigo, TTCL, Vodacom and Zantel with 47,761,520 voice telecom subscriptions (TCRA, 2019).

All the seven mobile phone companies 
currently operating in Tanzania strive at gaining more subscribers by providing attractive packages to their customers. More importantly, several strategies to make the companies known to their customers are used. Advertising is one of the leading promotional tools used for introducing the companies to the customers. Advertisement is an essential tool in the marketing of the company's products and connecting the customers to the services and products of the company. Jafari and Mahadi (2014) describe advertising as a form of business marketing that serves the roles of encouraging, persuading, manipulating or influencing the audience so that they can act or continue acting on the advertised products or services. Thus, advertisement bridges the communication gap between the company and its products on one hand and the customers on the other hand. In the absence of advertisement, it would be practically impossible for the targeted customers to be aware of the products and services offered by a given company.

It is with this significant role that adverts have become part and parcel of people's lives. We are surrounded with adverts everywhere in different forms, all intending to win potential customers for services and products. Companies present their adverts using different forms of media namely visual, which can be printed or in digital forms, audio and audio-visual communication.

Any communication is geared at achieving a particular purpose. Thus, a communicative purpose is at the heart of any advertisement. To be able to achieve the communicative intent, language plays a significant role. The choice of language to use is of paramount importance for achieving the desired goal i.e. making customers moved to act or continue acting on the services and products. With language at the centre, advertisers carefully select, prepare and produce advertisement texts for attracting attention from and arousing interest to the audience. Jafari and Mahadi (2014) give two major parts of an advert namely body content and a slogan.

What goes to the media for publicizing the company's products or services is usually a slogan. Therefore, much attention and careful choice of language is involved in preparing a slogan text. It is therefore imperative to understand the language employed in slogans that are used to advertise mobile phone companies.

Slogan language is studied in large scale using many linguistic theories including pragmatic theory. Various kinds of products' slogans have been analyzed such as airline slogans (Kurniawan, 2018), tourism slogans (Piyapong and Siriporn, 2018), and political campaign slogans (Amalancei, Buzoianu, and Buzoianu, 2017) but mobile phone company slogans have not seen much attention linguistically particularly in Tanzania. The current study is crucial because it presents the way slogans are used to unveil different illocutionary acts which imply that saying is equals to doing. For example through slogans different actions can be performed such as promising, directing and stating. The study unveils the applicability of the speech act theory in Swahili language as it offers pertinent examples drawn from the language. Therefore, this study sought to make a linguistic analysis of the selected mobile phone companies' slogans in Tanzania namely Tigo and Vodacom. The study was guided by two research questions namely:

1) What linguistic forms are used in the mobile phone companies' slogans?

2) What type of illocutionary speech acts are portrayed by the slogans?

In a capitalist economy which is largely competitive in nature, selling of the company's products or services depends on how the company and its services or products are known to the customers. Kohli, Leuthesser and Suri (2007) identify three key components that are used create the identity of the company or brand namely the brand name, logo and slogan. Of the three components, it is the slogan that, to a large extent, connects the company with the world surrounding it.

Slogans serve two major functions that is “creating a company's awareness and promoting, protecting or changing the image or perception of the brand" (Abdi and Irandoust, 2013, p. 65). The two are achieved through developing and efficiently using the slogans in marketing the company. A slogan is 
defined as a phrase or a sentence that captures the heart of advertisement's message (Applegate, 2005) usually of no more than three to seven words. A slogan as a tool for identifying a company or brand, are normally placed beneath a company's logo in a series of advertisement (Applegate, 2005). Being at the heart of advertisement, slogans carry with them meanings which can be interpreted as information, promise, and or encouragement to take action. Gouliamoset. al (2013) stress that such slogans' meanings are usually implicit. Therefore, a linguistic analysis of the slogans is important in understanding the language selected and employed to publicize the company or brand as well as uncovering the embedded pragmatic meanings.

Researches conducted have demonstrated the importance of analysing the slogans both in terms of the language forms employed and the pragmatic point of view for unveiling the implied meaning. Kurniawan, (2018) analysed the language of airlines slogans by analysing the syntactic categories, semantic claim and speech acts employed in the airline slogans. The findings indicate that most airlines slogans are phrases which employ 'we are different and unique' claim and in terms of speech acts, they are representative speech acts.

Similarly, Prabowo (2018) made a connection of language forms and meaning implied by advertising slogans. He intended to describe the linguistic forms and the implicature found in each slogan of commercial advertisements taken from the Time Magazine. He reveals in the findings, that slogans were mostly phrases and sentences, and findings indicate that all the analysed slogans had implied meanings which are useful in attracting readers' attention to buy the advertised products. The linguistic forms of the slogans were potential in exposing the phenomenon of implicature.

The above findings indicate that the analysis of the linguistic forms of slogans is essential in understanding the language of advertisement slogans. A linguistic form is defined as "a meaningful unit of language such as an affix, word, phrase or sentence" (Berube, 2005, p. 654). Therefore, every linguistic level of analysis contains a meaningful unit of analysis which is also termed as a linguistic form. The unit of analysis in pragmatics is a text, in syntax is a word, phrase and a sentence, in phonology is a phoneme and in morphology is a morpheme. However, in phonology and morphology what is physically realized is a phone and morph respectively. Therefore in analyzing a linguistic form in such levels, it would be a phone and morph that are identified to represent abstract entities namely a phoneme and morpheme. With this paper, the focus of analysis was at a syntactic level. Despite the importance of analysing a linguistic form, the analysis would not be complete without looking at the meaning conveyed by such slogans. Chiluwa (2007) views adverts as a type of discourse that performs actions. In order to unveil the actions performed by such adverts a pragmatic analysis of slogans is essential for unveiling adverts as a form of language in action. Thus, the investigation of meaning and function of language of adverts is central to linguistic analysis.

Some studies directly speculated on the pragmatic aspects of the slogans to uncover the implicit message communicated. Arrosid and Munandar (2018) in their study wanted to understand the most dominant illocutionary acts used in the slogans. From the findings, it was revealed that four types of acts are used in online airline advertising slogans namely directives, expressives, commissives and assertive but the last being most dominant. Contrary, Chiluwa (2007) found out only representational and persuasive acts are represented in advertisement slogans. The studies indicate that speech acts or meaning implied in the slogans vary from one context to the other.

Despite the variability of the findings, speech act theory has been instrumental in understanding the speech acts. As a pragmatic concept, speech act helps to understand the functionality of language both in the context of users and the situation. Whether written or uttered, language text bears the intention of the producer. Austin (1962) and Searle (1969) as cited in Chiluwa (2007) point out that an utterance or a written expression is viewed as performing some act which can be stating 
something (e.g. opinion), "confirming or denying, predicting, warning, denouncing, christening, promising, thanking or consoling" (p.5). It presupposes that users of language do not simply produce words but use words to accomplish something. Austin (1969) descriptively defines a speech act as the meaningful utterance with a certain conventional force bringing about a certain effect. Such a descriptive definition entail three aspects of speech act namely Locutionary, Illocutionary and Perlocutionary speech acts. Locutionaryis the act of producing a meaningful utterance or speech following the syntax, phonology and semantics of a particular language. Illocutionary act is the intended meaning behind the produced utterance which can be requesting, instructing, directing or promising. Perlocutionaryis the conventional or non-conventional effect that an utterance produces to the recipient. In communication process it can be described as a feedback produced for example crying, excitement, buying the advertised product and so on.

Of the three types of acts, illocutionary act is the most important in understanding the intended meanings of advertisement slogans. This is where we capture the actions performed through words. Austin (1962) in Chiluwa (2007) distinguishes statements that perform actions (performative utterances) from those that merely report or describe a state of affair (constative utterances). Five categories of performative acts were identified by Austin namely verdictives, exercitives, commissives, behabitives, and expositives. The classification was later improved by Searle (1972) who also came up with five categories of illocutionary acts namely assertives, directives, commissives, expressives and declaratives. Searle's classification is deemed a suitable classification that removes ambiguity in understanding and differentiating the acts. Assertives imply stating something and committing the hearer to the truth of the stated utterance. They can be said to be utterances that express facts. They employ verbs such as affirm, conclude, boast, deduce, believe etc. Directives are utterances that get the hearer to do something and the propositional content is for the hearer to perform some future actions. They include verbs such as order, command, beg, challenge, request etc. Commissives are acts which commit the speaker to some future actions. They include verbs such as promise, offer, swear, vow, guarantee etc. Expressives are acts that convey a psychological or mental state of the speaker. Verbs such as condole, apologize, deplore, appreciate, welcome, congratulate are used. Lastly, declaratives effect immediate changes in the status or condition of an object, situation or the institutional state of affairs. These acts are effectively performed by relying on extralinguistic institutions. For example, in declaring people husband and wife, a church or mosque as recognised institutions are required (Acheoah, 2017).

\section{Methodology}

The study employed content analysis technique. Krippendorp (2004) quoted in Cohen, Manion and Morrison (2007:475) defines content analysis as 'a research technique for making replicable and valid inferences from texts to the contexts of their use'. The term text broadly represents any piece of language which can be spoken or written that fulfils a communicative intent in a given context. However, the word text as used in this paper represents 'any written communicative materials which are intended to be read, interpreted and understood by people other than the analysts' (Cohen, Manion and Morrison, 2007: 475). Singh (2006) argues that content analysis is more suitable when records or documents (texts) are used as sources of data. Thus, content analysis was selected because the analysed data were extracted from the texts.

The analysed data were slogans taken from online websites of the Tigo and Vodacom mobile phone companies. 20 slogans are in Swahili language and 5 slogans are in English. The English language is opted for capturing the international customers especially in the business section of the websites. Documentation method was employed in the collection of data, whereby slogans found on the companies' websites were taken and written down. A total of 25 slogans were extracted from the online websites of the two companies accessed on 26/11/2019 at 14:25 for Vodacom (https://vodacom.co.tz/en/) and 
on $26 / 11 / 2019$ at $14: 54$ for Tigo (https://www.tigo.co.tz).

Data were analysed in line with the content analysis' procedures. Content analysis involves coding, categorizing, comparing and drawing theoretical conclusions from the text (Cohen, Manion and Morrison, 2007; Berg, 2001). Thus the collected data were coded using the following codes: $1=$ datum number, MPS=Mobile Phone Slogan, V=Vodacom and T=Tigo, example; $1 /$ VMPS or $1 /$ TMPS). Then data were categorized according to the company'; described on the basis of structural grammar and lastly data explanation was done using the speech act theory to uncover the types of illocutionary speech acts portrayed by the slogans.

Two companies namely Tigo and Vodacom were purposefully sampled from the 8 mobile phone companies that are operating in Tanzania. Tigo was selected because it is the first company to provide mobile services in Tanzania by then known as Mobitel (Mtenzi, Chachage, and Ngumbuke, 2008). Vodacom was selected because it is the company that is leading in terms of the numbers of mobile phone subscribers in Tanzania. It has 15.67 million subscribers followed by Airtel 12.72 million, Tigo 12.57 million, Halotel 4.64 million, Zantel 1.17 million, TTCL 0.98 million and lastly Smile 0.001 million (TCRAQuarterly December report, 2019).

\section{Results and Discussion}

A total of 25 slogans (all slogans found in the websites by the time of access) were collected and analysed from the two mobile phone companies in Tanzania namely Vodacom and
Tigo. The data were collected and analysed to address two research questions namely: What Linguistic forms are used in the mobile phone companies' slogans? and What type of illocutionary speech acts are portrayed by the slogans?

\section{Linguistic Forms of the Mobile Phone's Slogans}

From the analysed data, it was found out that the mobile phone's slogans are framed in three linguistic forms namely; word, phrase and sentence. All the identified linguistic forms in the analysed data are units of analysis in the syntactic level from the smallest (word) to the largest (sentence) unit of analysis. The findings on the linguistic forms of the slogans are summarised in table 1.

Table 1 indicates the linguistic forms of the analysed mobile phone slogans. The results indicate that sentences dominate as the linguistic form with 19 occurrences out of 25 analysed slogans. This accounts for $76 \%$ percent. The second linguistic form is a phrase with a frequency of 5 accounting for $20 \%$. From the findings all the phrases identified are noun phrases. Lastly is a word form with only 1 occurrence. From these findings, the choice of sentences as a linguistic form for mobile phone's slogans is preferable. These findings are contrary to Kurniawan (2018) who found out that most airline slogans employed phrases. This indicates therefore, that when it comes to transportation adverts short slogans are preferable compared to services adverts where sentences would be compiling to convey the intended message

Table 1.Linguistic Forms of the Analysed Slogans

\begin{tabular}{|c|l|c|c|c|c|}
\hline S/N & \multicolumn{1}{|c|}{ Slogan } & Data type & Word & Phrase & Sentence \\
\hline 1 & Secure a brighter future with vodashule & 1VMPS & & & $\checkmark$ \\
\hline 2 & Usichukuliepoaukapitwa & 2VMPS & & & $\checkmark$ \\
\hline 3 & Janjarukana UNI bando & 3VMPS & & & $\checkmark$ \\
\hline 4 & Yajayoyanafurahisha, ukotayari? & 4VMPS & & & $\checkmark$ \\
\hline 5 & $\begin{array}{l}\text { Are you ready to take your business to the } \\
\text { next level? }\end{array}$ & 5VMPS & & & $\checkmark$ \\
\hline 6 & Pinduapindua & 6VMPS & $\checkmark$ & & \\
\hline
\end{tabular}




\begin{tabular}{|c|c|c|c|c|c|}
\hline $\mathbf{S} / \mathbf{N}$ & Slogan & Data type & Word & Phrase & Sentence \\
\hline 7 & Kweli, pesanimpesa & 7VMPS & & & $\checkmark$ \\
\hline 8 & $\begin{array}{l}\text { Tanzania mpaka Kenya PesaniMpesa-es } \\
\text { Money Transfer }\end{array}$ & 8VMPS & & & $\checkmark$ \\
\hline 9 & SongeshanaMpesa & 9VMPS & & & $\checkmark$ \\
\hline 10 & LipakwaMpesa & 10VMPS & & & $\checkmark$ \\
\hline 11 & Hapamalipondionyumbani & 11VMPS & & & $\checkmark$ \\
\hline 12 & Faidikana halal yaamanipesa & 12VMPS & & & $\checkmark$ \\
\hline 13 & M-kobandiyohabariyavikundi & 13VMPS & & & $\checkmark$ \\
\hline 14 & M-kobandiyohabariyafamilia na marafiki & 14VMPS & & & $\checkmark$ \\
\hline 15 & $\begin{array}{l}\text { Your fully cashless business } ₫ \text { Our efficient } \\
\text { Mpesa for business service }\end{array}$ & 15VMPS & & $\checkmark \quad \mathrm{NP}$ & \\
\hline 16 & $\begin{array}{l}\text { Your competitive business Our all in one } \\
\text { SIM manager platform }\end{array}$ & 16VMPS & & $\checkmark \quad \mathrm{NP}$ & \\
\hline 17 & $\begin{array}{l}\text { Your globally connected business our } \\
\text { reliable Vodacom network }\end{array}$ & 17VMPS & & $\checkmark \quad \mathrm{NP}$ & \\
\hline 18 & $\begin{array}{l}\text { Your business continued relevance our } \\
\text { mobile voice and data solution }\end{array}$ & 18VMPS & & $\checkmark \quad \mathrm{NP}$ & \\
\hline 19 & Jipatiekitochi 4G smart yakosasa & 1TMPS & & & $\checkmark$ \\
\hline 20 & $\begin{array}{l}\text { ya kwanza Tanzania-Home internet } \\
\text { kutokatigo }\end{array}$ & 2TMPS & & $\checkmark \quad \mathrm{NP}$ & \\
\hline 21 & Pata GB 78 bure kwamiezi 24 & 3TMPS & & & $\checkmark$ \\
\hline 22 & $\begin{array}{l}\text { Patahadi GB } 3 \text { zakutumiawhatsapp, } \\
\text { Instagram, Facebook naTwiterkuanzia } \\
\text { Sh.1000 }\end{array}$ & 4TMPS & & & $\checkmark$ \\
\hline 23 & Pokeapesauongezewepesa & 5TMPS & & & $\checkmark$ \\
\hline 24 & Tigo pesa nizaidiya pesa & 6TMPS & & & $\checkmark$ \\
\hline 25 & Tigo live it, love it & 7TMPS & & & $\checkmark$ \\
\hline & TOTAL & & $\begin{array}{c}01 \\
(14 \%)\end{array}$ & $\begin{array}{c}05 \\
(20 \%)\end{array}$ & $\begin{array}{c}19 \\
(76 \%)\end{array}$ \\
\hline
\end{tabular}

From the findings, the most employed sentence types are declarative and imperative sentences which have equal occurrence of 9 times each accounting for $47.4 \%$ each. Only one interrogative sentence has been employed nevertheless the sentence does not aim at seeking information from the customer. It is simply a rhetoric type of interrogative sentence. The two sentences types dominate simply because the companies are interested in revealing the services available (declarative sentences) and directing customers on how to benefit from the services offered (imperative sentences). For example, Tanzania mpaka Kenya pesa ni Mpesa (From Tanzania to Kenya, Money is M-Pesa). This slogan indicates that Vodacom offers services of money transaction across Tanzania and Kenya. Thus, money transactions can easily be carried out using Mpesa services. In line with the services available, another slogan is given as a directive to customers which is lipa kwa Mpesa (pay by Mpesa). It directs customers to use Mpesa services to make payments and any others financial transactions. A summary of the sentencetypes from the analysed slogans is presented in table 2 . 
Table 2. Sentence Types in Analysed Slogans

\begin{tabular}{|c|c|c|c|c|c|}
\hline $\mathbf{S} / \mathbf{N}$ & Slogan & SK 1 & SK2 & SK3 & SK4 \\
\hline 1 & Secure a brighter future with Vodashule & & $\checkmark$ & & \\
\hline 2 & $\begin{array}{l}\text { Usichukuliepoaukapitwa- Don't take it for granted } \\
\text { and miss it }\end{array}$ & & $\checkmark$ & & \\
\hline 3 & $\begin{array}{l}\text { Janjarukana UNI bando- Become alert with UNI } \\
\text { bundle }\end{array}$ & & $\checkmark$ & & \\
\hline 4 & $\begin{array}{l}\text { Yajayoyanafurahisha, ukotayari?-The future is } \\
\text { exciting, are you ready? }\end{array}$ & $\checkmark$ & & & \\
\hline 5 & $\begin{array}{l}\text { Are you ready to take your business to the next } \\
\text { level? }\end{array}$ & & & $\checkmark$ & \\
\hline 6 & Kweli, pesanimpesa- True, Money is Mpesa & $\checkmark$ & & & \\
\hline 7 & $\begin{array}{l}\text { Tanzania mpaka Kenya Pesani M-pesa- From } \\
\text { Tanzania to Kenya, Money is M-Pesa }\end{array}$ & $\checkmark$ & & & \\
\hline 8 & SongeshanaMpesa- Make it Possible with Mpesa & & $\checkmark$ & & \\
\hline 9 & LipakwaMpesa- Pay by Mpesa & & $\checkmark$ & & \\
\hline 10 & $\begin{array}{l}\text { Hapamalipondionyumbani- It is the home of making } \\
\text { payments }\end{array}$ & $\checkmark$ & & & \\
\hline 11 & $\begin{array}{l}\text { Faidikana halal ya Amani pesa -Benefit from halal of } \\
\text { Aman money }\end{array}$ & $\checkmark$ & & & \\
\hline 12 & $\begin{array}{l}\text { M-kobandiyohabariyavikundi- } M \text {-Koba is a good } \\
\text { news for small business groups }\end{array}$ & $\checkmark$ & & & \\
\hline 13 & $\begin{array}{l}\text { M-kobandiyohabariyafamilianamarafiki- } M \text {-koba is a } \\
\text { good news for families and friends }\end{array}$ & $\checkmark$ & & & \\
\hline 14 & $\begin{array}{l}\text { Jipatiekitochi } 4 \mathrm{G} \text { smart yakosasa- Get your kitochi } 4 G \\
\text { now }\end{array}$ & & $\checkmark$ & & \\
\hline 15 & $\begin{array}{l}\text { Pata GB } 78 \text { bure kwamiezi 24- Get } 78 \text { GB free in } 24 \\
\text { months }\end{array}$ & & $\checkmark$ & & \\
\hline 16 & $\begin{array}{l}\text { Patahadi GB } 3 \text { zakutumiawhatsapp, Instagram, } \\
\text { Facebook naTwiterkuanzia Sh.1000- Get up to } 3 \text { GB } \\
\text { for WhatsApp, Instagram, Facebook and Twitter at a } \\
\text { cost staring from Tsh. } 1000\end{array}$ & & $\checkmark$ & & \\
\hline 17 & $\begin{array}{l}\text { Pokeapesauongezewepesa- Receive money, get } \\
\text { added money }\end{array}$ & & $\checkmark$ & & \\
\hline 18 & $\begin{array}{l}\text { Tigopesani Zaidi yapesa- TigoPesa is more than } \\
\text { money }\end{array}$ & $\checkmark$ & & & \\
\hline 19 & Tigo live it, love it & $\checkmark$ & & & \\
\hline \multicolumn{2}{|c|}{ TOTAL } & 9 & 9 & 1 & $\mathbf{0}$ \\
\hline
\end{tabular}

KEY: SK1 = Declarative, SK2 = Imperative, $S K 3=$ Interrogatives, $S K 4=$ Exclamative Source: Researchers, (2020)

Few slogans employed a phrase form, and all of them used noun phrase. Slogans that employed a phrase form are presented in pairs to indicate what the company has and how a customer can benefit from the company. For example, Your business continued relevance, our mobile voice and data solution (18VMPS). From this slogan, a customer is assured the 
mobile voice and data services offered by the company can help to make his/her business have a continued relevancy.

\section{Types of Illocutionary Acts Portrayed by the Slogans}

Mobile phone slogans were analysed using speech act theory to uncover the type of illocutionary acts portrayed by the slogans. Searle's classification of illocutionary acts was employed to analyse the slogans. The findings are presented in table 3 . The findings presented in table 3 can be summarised in terms of percentages as presented in table 4 .

Table 3. Illocutionary acts portrayed by slogans.

\begin{tabular}{|c|c|c|c|}
\hline $\mathbf{S} / \mathbf{N}$ & Slogan & $\begin{array}{l}\text { Data } \\
\text { Code }\end{array}$ & $\begin{array}{c}\text { Type of } \\
\text { illocutionary act }\end{array}$ \\
\hline 1 & Secure a brighter future with vodashule & 1VMPS & Directive \\
\hline 2 & Usichukulie poa ukapitwa & 2VMPS & Directive \\
\hline 3 & Janjarukana UNI bando & 3VMPS & Directive \\
\hline 4 & Yajayo yanafurahisha, ukotayari? & 4VMPS & Commissives \\
\hline 5 & Are you ready to take your business to the next level? & 5VMPS & Directive \\
\hline 6 & Pinduapindua & 6VMPS & Assertive \\
\hline 7 & Kweli, pesanimpesa & 7VMPS & Assertive \\
\hline 8 & $\begin{array}{l}\text { Tanzania mpaka Kenya PesaniMpesa- } \text { Money } \\
\text { Transfer }\end{array}$ & 8VMPS & Assertive \\
\hline 9 & SongeshanaMpesa & 9VMPS & Directive \\
\hline 10 & LipakwaMpesa & 10VMPS & Directive \\
\hline 11 & Hapamalipondionyumbani & 11VMPS & Assertive \\
\hline 12 & Faidikana halal yaamanipesa & 12VMPS & Commissives \\
\hline 13 & M-kobandiyohabariyavikundi & 13VMPS & Assertive \\
\hline 14 & M-kobandiyohabariyafamilia na marafiki & 14VMPS & Assertive \\
\hline 15 & $\begin{array}{l}\text { Your fully cashless business } \text { Our efficient Mpesa for } \\
\text { business service }\end{array}$ & 15VMPS & Assertive \\
\hline 16 & $\begin{array}{l}\text { Your competitive business Our all in one SIM } \\
\text { manager platform }\end{array}$ & 16VMPS & Assertive \\
\hline 17 & $\begin{array}{l}\text { Your globally connected business our reliable } \\
\text { Vodacom network }\end{array}$ & 17VMPS & Assertive \\
\hline 18 & $\begin{array}{l}\text { Your business continued relevance our mobile } \\
\text { voice and data solution }\end{array}$ & 18VMPS & Assertive \\
\hline 19 & Jipatiekitochi 4G smart yakosasa & 1TMPS & Commissive \\
\hline 20 & ya kwanza Tanzania-Home internet kutokatigo & 2TMPS & Assertive- \\
\hline 21 & Pata GB 78 bure kwamiezi 24 & 3TMPS & Commissive \\
\hline 22 & $\begin{array}{l}\text { Patahadi GB } 3 \text { zakutumiawhatsapp, Instagram, } \\
\text { Facebook naTwiterkuanzia Sh.1000 }\end{array}$ & 4TMPS & Directive \\
\hline 23 & Pokeapesauongezewepesa & 5TMPS & Commissives \\
\hline 24 & Tigo pesa nizaidiya pesa & 6TMPS & Assertive \\
\hline 25 & Tigo live it, love it & 7TMPS & Commissives \\
\hline
\end{tabular}


Table 4. Type of illocutionary acts in the mobile phone's slogans

\begin{tabular}{|l|c|c|}
\hline \multicolumn{1}{|c|}{ Type of illocutionary force } & Number of slogans & Percentage \\
\hline Assertives & 12 & 48 \\
\hline Commissives & 6 & 24 \\
\hline Directives & 7 & 28 \\
\hline Expressives & 0 & 0 \\
\hline Declaratives & 0 & 0 \\
\hline Total & $\mathbf{2 5}$ & $\mathbf{1 0 0}$ \\
\hline
\end{tabular}

Table 4 indicates that the analysed slogans portrayed three types of illocutionary acts namely assertive (48\%), commissives (24\%), and directives $(28 \%)$. These findings indicate that mobile phone companies are interested in making the customers believe in their products and services advertised, take action of either buying the advertised products or subscribe to the services and lastly companies promise a better service or products to their customers if the customers opt to join their advertised products and services. These findings are in agreement with Arrosid and Munadar (2018) who also found out commissive, directives and assertive to be dominant acts in slogans and assertive act being most dominant. The rest two types of illocutionary acts namely expressive and declaration do not feature in the slogans simply because the companies are not interested in changing the status quo of their customers nor are they interested to express their psychological state towards their services and products. If that is done, it would end up discouraging the customers to opt for the advertised products and services.

From the findings, the dominant illocutionary act portrayed by the slogans is assertive (48\%). This indicates that mobile phone companies put much emphasises on asserting the customers to buy the advertised products or services by convincing the customers to believe that the advertised products and services are good. Out of the 25 slogans analysed, 12 slogans portrayed assertive acts. Some examples of the slogans that portray assertive act are
1) ya kwanza Tanzania-Home internet kutoka Tigo (2TMPS)

the first in Tanzania- home internet from Tigo (Translation)

2) Your globally connected business, our reliable Vodacom network (17VMPS)

Declarative utterance acts as one of the indicative device for identifying utterance as an assertion (Recanati, 2013).The exemplified slogans above portray assertive act which is expressed in declarative utterances.Thus, in this context, assertive act is not attributed to a single word as an indicative device but to an entire expression. Generally, it is the communicative intent of the expression that determines the act that is being performed. Example number 1(a) with its translation 1(b) aims at making customers believe and subscribe to the internet from Tigo since it is presented in the slogan as the first home internet. In other words, if the customer has to choose among the available home internet in the market, the first option should be Tigo internet. Example number 2 affirms to the customers that if one wants a globally connected business then the internet that is reliable to assure the connectivity is Vodacom network. All these aim at attracting certain type of customers to the internet service provided by mobile phone companies in Tanzania.

The second illocutionary act that feature in the slogans is directive. It is a type of act that requires the addressee to do something. It has appeared the second in terms of frequency of occurrence because when the customer is convinced by the advertised products and services then is expected to take action. The slogans that portrayed directive act are as follows 
3) Pata had GB 3 za kutumia whatsapp, Instagram, Facebook na Twiter kuanzia Sh.1000

Get up to 3 GB for WhatsApp, Instagram, Facebook and Twitter at a cost staring from Tsh. 1000

4) Are you ready to take your business to the next level?

5) Usichukulie poa ukapitwaa Don't take it for granted to miss it

6) Secure a brighter future with vodashule

7) Janjaruka na UNI bando Become alert with UNI bando

8) Songesha na Mpesa Make it Possible with Mpesa

9) Lipa kwa Mpesa (Pay with Mpesa) Pay by Mpesa

All the above slogans are directives but perform different sub-acts. Example number 6, 8 and 9 indicate ordering. They are more of ordering the customers to take a course of action. For instance, example number 9 lipa kwa Mpesa (pay by Mpesa) requires the customers to carry out financial payments through Mpesa. The order is justified by the linguistic form of the slogan. The slogan begins with a verb lipa (pay) which indicates the whole expression is a command. Example 3 indicates invitation, 4 shows asking, 5 shows insisting and 7 indicates challenging.

The third illocutionary act is commissive. This type of act commits the speaker to some future course of action. The occurrence of commissive act indicate that the mobile phone companies by advertising their products and services they warrantee their products and services can be reliable but also show how customers can benefit from the companies with multiple bonuses. Examples of slogans that have portrayed this act include:

10) Yajayo yanafurahisha, ukotayari? (The future is exciting, are you ready?)

11) Jipatie kitochi $4 G$ smart yako sasa (Get a 4G smart kitochi now)

12) Pokea pesa uongezewe pesa (Receive money, get added money)

Example 10 is commissive act as it shows a promise. The customer is promised of a better service in future when he/she joins the company.

\section{Conclusion}

The findings from the study have indicates that slogans for advertising mobile phone services and products may take different linguistic forms of which largely falls within the syntactic level of linguistic analysis. However, it has been revealed that the preference is more on sentences. With these findings, it is concluded that sentences are useful linguistic forms in constructing slogans that can convey intended message to the audience.

Secondly, findings have shown that any slogan that is constructed to communicate a message carries within it an implied meaning. The study has revealed using speech act theory the slogans used by Vodacom and Tigo companies intend to change beliefs of customers (assertive) and make them take particular actions in regard to the services and products advertised (directive). This is accompanied by promising better services and products for the opting customers (commissive). The study was confined in looking at the illocutionary speech acts portrayed by the slogans to uncover embedded meanings in the slogans; however, other studies can be done to make a comparative analysis of the characteristic features of the slogans from the two companies.

Finally, this study analysed the linguistic form of the slogans and looked at the implied meaning using the speech act theory. However, other researches can be done to uncover other pragmatic meaning of the slogans. Furthermore, other linguistic theories such as functional grammar can be employed to uncover the functionality of the slogans. 


\section{References}

Abdi, S., \& Irandoust, A. (2013). The importance of Advertising Slogans and their proper designing in brand equity. International journal of Organizational Leadership, 2(2), 62-69

Acheoah, J. E. (2017). Searle's Speech Act Theory: An Integrative Appraisal. American. Research Journal of English and Literature.

Amalancei, B. M., Buzoianu, C. C \& Buzoianu, C. D. (2017). Looking For the Best Slogan: An Analysis of the Slogans of the 2016 Romanian Parliamentary Campaign. Studies and Scientific Researches, 26

Applegate, E. (2005). Strategic copywriting: how to create effective advertising. New York: Rowman and Littlefield publishers Inc.

Arrosid, I., \& Munandar, A. (2018). Illocutionary Acts in Online Airline Advertising Slogans. LEXICON, 5(1), 4654.

Berg, B.L (2001). Qualitative Research Methods for the Social Sciences. London: Allyn\& Bacon.

Berube, M.S. (2005). Webster's II New College Dictionary. New York: Houghton Mifflin company.

Bloor, T. \& Bloor, M. (2013). The Functional Analysis of English: A Hallidayan Approach. New York: Routldege

Chiluwa, I. (2007). A Speech Act Analysis of Written Adverts of Soft Drinks in Nigeria. Babcock Journal of Mass Communication, 1(3).

Cohen, L. Manion, L. \& Morrison, K. (2007). Research Methods in Education. New York: Routledge.
Gouliamos, K., Theocharous, A., \& Newman, B. (2013). Political Marketing: Strategic Campaign Culture. New York: Routledge

Jafari S.M and Mahadi, T.S.T. (2014). The language of advertisement and its features and Characteristics: investigating the issue from a deeper view. International Journal of English and Literature (IJEL), 4(6).

Kohli, C., Leuthesser, L., \& Suri, R. (2007). Got slogan? Guidelines for creating effective slogans, Journal of Business Horizon, 50, 415- 422.

Kurniawan, I. (2018). The Language of Airline Slogans: A Linguistics Analysis. English Education Journal, 11(1), 59

Mtenzi, F. J, Chachage, B. L, \&Ngumbuke, F (2008). The Growth of Tanzanian Mobile Phone Sector: Triumph of Quantity, Failure of Quality? Proceedings of M4D 2008, Karlstad University, Sweden - 55

Piyapong, L., \&Siriporn, P. (2018). A Factor for Interpreting Tourism Slogan. Journal of language and linguistics, 36(2)

Prabowo, W (2018) Linguistic Forms and Implicature Analysis of Advertising Slogans Found InTime Magazine English Language \& Literature Journal, VII(7)

Singh, Y.K. (2006). Fundamentals of Research Methodology and Statistics. Mumbai: New Age International Publishers.

TCRA (2019) Quarterly communication statistics: October-December, from http.www. tcra. com accessed on $19^{\text {th }}$ March, 2020 at 12:30pm.

Recanati, F. (2013) Content, mood, and force. Philosophy Compass 8(7), 622-632.

https://vodacom.co.tz/en/ accessed on $26 / 11 / 2019$ at $14: 25$

https://www.tigo.co.tz accessed on $26 / 11 / 2019$ at $14: 54$ 